\title{
IUGS financial statement for 1992, budget for 1993
}

1. Income

Grants from ICSU fund

UNESCO IGCP contracts

UNESCO contribution to Geoenvironmental Workshop for 1991 ${ }^{1}$

UNESCO contribution to GARS (1991/1992) ${ }^{1}$

UNESCO contribution to Deposit Modelling ${ }^{1}$

UNESCO contribution to Climates of the Past ${ }^{1}$

Contributions from National Members ${ }^{2}$

Contributions from Associate Members

US contribution to IGCP and related projects

UK contribution to IGCP and related projects (1993)

Bank interest

Sales of publications, royalties

Miscellaneous receipts

Loss on exchange

Total receipts

2. Expenditures

2.1 Scientific activities

IUGS Commissions, Boards, Committees, Working Groups (Schedule A)

Research projects

- IGCP projects

- Circum-Atlantic Project

- GARS

- Deposit Modelling

- Climates of the Past

- Inter-Union Commission on the Lithosphere

- ICSU programs (Sedimentary, Education, Environment)

Grants to Affiliated Organizations (Schedule B)

IUGS contribution to

$$
\begin{aligned}
& \text { - ICSU } \\
& \text { - CTS } \\
& \text { - ICSTI }
\end{aligned}
$$

2.2 Meetings, conferences

Routine meetings

Scientific meetings

2.3 Publications

Episodes ${ }^{6}$

2.4 Administrative expenses

Operating costs and supplies

Miscellaneous expenses, audit

Bank charges

Contingency

\section{Total expenses}

Transfer to reserve account ${ }^{7}$

Total expenses including transfer to reserve account

3. Excess of income over expenditure

\begin{tabular}{|c|c|}
\hline $21,200.00$ & $21,200.00$ \\
\hline 169.000 .00 & $173,000.00$ \\
\hline $1,000.00$ & -- \\
\hline $11,000.00$ & $6,000.00$ \\
\hline 9.000 .00 & $3,000.00$ \\
\hline $8,000.00$ & $8,000.00$ \\
\hline $182,872,85$ & $210,000.00$ \\
\hline $9,100.00$ & $9,000.00$ \\
\hline $80,000.00$ & 80.000 .00 \\
\hline $52,764.68$ & $52,760.00$ \\
\hline $6,731.84$ & 5.000 .00 \\
\hline 314.00 & -.- \\
\hline $18,594.84$ & $16,000.00^{3}$ \\
\hline-402.78 & --- \\
\hline$\overline{569,175.43}$ & $\overline{583,960.00}$ \\
\hline $53,647.00$ & $55,500.00$ \\
\hline $305,600.00$ & $321,260.00$ \\
\hline $4,783.94$ & $3,300.00^{4}$ \\
\hline $20,000.00$ & $9,000.00$ \\
\hline $19,000.00$ & $13,000.00$ \\
\hline $9,000.00$ & $16,000.00$ \\
\hline $20,000.00$ & $20,000.00$ \\
\hline $15,900.00$ & $19,200.00$ \\
\hline 8.000 .00 & $4,000.00$ \\
\hline $5,422.00$ & $6,400.00$ \\
\hline 400.00 & 400.00 \\
\hline 619.65 & 600.00 \\
\hline $21,233.35$ & $40,000.00$ \\
\hline $2,000.00$ & $3,000.00$ \\
\hline $37,000.00$ & $44,300.00$ \\
\hline -.- & $2,000.00$ \\
\hline $11,491.84$ & $8,000.00$ \\
\hline $3,205.17$ & $3,000.00$ \\
\hline 820.00 & $5,000.00$ \\
\hline \multirow[t]{3}{*}{$\overline{538.122 .95}$} & $\overline{573,960.00}$ \\
\hline & $10,000.00$ \\
\hline & $\overline{583,960.00}$ \\
\hline
\end{tabular}

4. Status of accounts (US\$)

4.1 IUGS operational account

Accumulated cash balance at January 1, 1992

Accumulated cash balance at December 31, 1992

$$
\text { - Reston account }
$$

- Hannover account

$90,973.95$

Outstanding receipts at December 31, 1992

UNESCO for IGCP and other contracts

$31,052.48$

$158,661.64$

Outstanding payments at December 31, 1992

Excess of receivable over payable

4.2 IUGS reserve account

Status at December 31, 1991

Status at December 31, 1992
a, Security bonds
b, Short-time investments

$108,681.03$

$22,000.00$

$22,000.00$

$66,625.00$

131.300 .00 


\section{IUGS financial statement for 1992, budget for 1993-Continued}

$1992(\mathrm{US} \$)$

$1993(\mathrm{US} \$)$

4.3 Hutchison Fund

Status at December 31, 1991

0.00

Status at December 31, 1992

$16,358.08$

4.4 Trondheim account ${ }^{\$}$

\section{Notes to the 1992 financial statement}

The financial statement presented here is based on the ICSU guidelines. It gives information about the IUGS accounts in Hannover and Reston; it does not include the local currency account in Moscow.

NOTE 1:

- 51 projects were funded by UNESCO in 1992.

- The US\$1,000 contribution to the Geoenvironmental Workshop represents the final payment of the UNESCO contribution for the year 1991

- The 1992 UNESCO contribution to GARS amounted to US $\$ 10,000$ of which US $\$ 9,000$ was received in 1991. US\$2,000 represents the final payment of the 1991 contribution to GARS

- The 1992 UNESCO contribution to Deposit Modelling amounted to US\$10,000 of which US\$9,000 was received in 1991

- The 1992 UNESCO contribution to CLIP amounted to US $\$ 9,000$, of which US $\$ 8,000$ was received in 1991 .

NOTE 2:

Member countries pay annual contributions according to their selected category of membership as outlined in the following table:

$\begin{array}{lrrrrrrrr}\text { Category } & 1 & 2 & 3 & 4 & 5 & 6 & 7 & 8 \\ \text { Contribution* } & 1 & 2 & 4 & 7 & 12 & 29 & 35 & 70\end{array}$

*Valued at US\$400.00 per unit as of July 15, 1989

According to the decision of the IUGS Council at its meeting in Washington, D.C., in July 1989 , all countries delinquent in paying their annual dues for more than 2 years will be put on inactive status. To regain the active status, dues for the current year plus the previous 2 years have to be paid. All other previous pending dues will be released automatically. At December 31, 1992. outstanding payments of active members totaled US $\$ 54,490$.

\section{NOTE 3:}

Includes carryover from 1992 to 1993 : Commission on lgneous and Metamorphic Petrogenesis, Subcommission on Gondwana Stratigraphy, Circum-Atlantic Project, Commission on Geological Education and Training, and Association of Geoscientists for International Development.

NOTE 4:

Of the carryover from 1991 to 1992 that amounted to US $\$ 8.084$, CAP withdrew US $\$ 4,784.00$. The remaining funds of US $\$ 3,300$ have been carried over to 1993 .
Schedule A

Payments to Commissions (US\$)

\begin{tabular}{|c|c|c|}
\hline & 1992 & 1993 \\
\hline CIMP $^{\mathrm{a}}$ & $(5,000,00)$ & $5,000.00$ \\
\hline COGEODOC $^{\mathrm{b}}$ & $4,000.00$ & -.- \\
\hline COGEODATA $^{b}$ & $5,000.00$ & ... \\
\hline COGEOINFO $^{\mathrm{b}}$ & $\cdots$ & $10,000.00$ \\
\hline INHIGEO & $3,000.00$ & $3,000.00$ \\
\hline Marine Geology ${ }^{\mathrm{c}}$ & $(4,000.00)$ & -- \\
\hline Systematics in Petrology & $8,047.00$ & $8,000.00$ \\
\hline COMTEC & $4,000.00$ & $3,000.00$ \\
\hline Stratigraphy ${ }^{d}$ & $21,600.00$ & $20,000.00$ \\
\hline Comparative Planetology & $(3,000.00)$ & -- \\
\hline Global Sedimentary Geology & $1,000.00$ & $1,500.00$ \\
\hline COGEOED & $\cdots$ & $\ldots$ \\
\hline Fossil Fuels & $4,000.00$ & $4,000.00$ \\
\hline COGEOENVIRONMENT & $3,000,00$ & $1,000.00$ \\
\hline $\mathrm{ABRD}^{\mathrm{C}}$ & $(1,000.00)$ & -- \\
\hline Total & $53,647.00$ & $55,500.00$ \\
\hline
\end{tabular}

a Carryover to 1993.

'In 1993, COGEODOC and COGEODATA are merged into COGEOINFO.

- Allocated but not withdrawn.

${ }^{\circ}$ US $\$ 25,000$ allocated but only US $\$ 21,600$ withdrawn.

e Allocation for 1993 increased from US $\$ 1,000$ to U\$ $\$ 3,000$.

\section{Schedule B}

\section{Payments to Affiliated Organizations (US\$)}

\begin{tabular}{|c|c|c|}
\hline & 1992 & 1993 \\
\hline $\mathrm{AGID}^{\mathrm{a}}$ & $(2,000.00)$ & $2,000.00$ \\
\hline CGMW & $2,500.00$ & $2,000.00$ \\
\hline GSAf & $2,500.00$ & $-\cdots$ \\
\hline IAEG & $1,000.00$ & $\ldots$ \\
\hline $\mathrm{IAH}^{\mathrm{b}}$ & $(2,000.00)$ & --- \\
\hline $\mathrm{AGA}^{\mathrm{b}}$ & $(1,000.00)$ & --- \\
\hline INQUA & $2,000.00$ & $\ldots$ \\
\hline Total & $8,000,00$ & $4,000.00$ \\
\hline
\end{tabular}

a Carryover to 1993.

Allocated but not withdrawn.

NOTE 5:

IUGS paid in 1992 an annual contribution to ICSU based on 2.5 percent of receipts out of IUGS membership fees. The contribution for 1993 was raised to 3.5 percent.

NOTE 6:

IUGS payments to Episodes represent support for printing and related costs.
NOTE 7:

See item 4.2 .

NOTE 8:

1992 expenses were paid by the Geological Survey of Norway. 